\section{More support for solid-Earth?}

THE community of solid-Earth geophysicists in the United Kingdom is inadequately represented and supported by the Natural Environment Research Council (NERC). That at least is the message from a recent survey of university Earth scientists carried out under the auspices of the Royal Astronomical Society. And, while NERC rejects some of the charges levelled at the way it assesses studentship and research proposals, there is no argument that the level of geophysical activity in the United Kingdom represents a significantly small proportion of efforts in the Earth sciences as a whole.

The charges implicitly levelled at NERC arise from a survey carried out by Professor K. Creer, head of the department of geophysics at the University of Edinburgh; those who responded included geophysicists and geologists from many British universities. The areas of concern include electromagnetics, geomagnetism, gravity and geodesy, palaeomagnetism, seismology and planetology.

One worry, according to Professor Creer's report on the survey, concerns the way in which NERC committees operate. The training awards committee for the Earth sciences, consisting of 17 scientists, does not use peer review in reaching its decisions - because according to NERC, the resources are not available to cope with such an assessment of 600 or so applications each year, of which about 130 are successful. Moreover, NERC's view is that anyone assessing an application within the United Kingdom would be a competitor, and that it would be impractical to have the applications assessed overseas.

The survey highlights the difference in classification between geophysicists with geological backgrounds on the one hand and those who apply expertise in physics and mathematics to geophysical problems on the other. If the latter category is accepted as the " "pure" definition of a geophysicist then, over the past decade, fewer than 10 per cent of the members of training awards and research grants committees have been geophysicists.

NERC's response is that it is keen to ensure that committee members are not seen as representatives of particular lobbies; rather, they should be capable of judging across all the fields concerned, with the help of peer review.

One feature of NERC policy highlighted by the survey is a concentration on crustal studies. Most geophysicists who responded work in this area and were satisfied with NERC's approach, except to question the relatively small amount of NERC's resources put into university research rather than other NERC activities (especially its own research institutes). The survey says, however, that such areas as electromagnetic induction, physical pro- perties of rocks and palaeomagnetism with geomagnetic objects are experiencing undue difficulties - a point that NERC simply rejects. One significant area of crustal research is the deep seismic crustal profiling project (affectionately known as BIRPS). The survey report points out that, as this involves extensive outside contracts in its operation and crustal geological interpretation, it should hardly be counted as real geophysics, and that, moreover, it has prejudiced support for geophysics by its sheer financial requirements. On the latter point, NERC says it was encouraged by ABRC to concentrate on certain areas likely to be particularly productive - an approach amply justified, it says, by the results of the deep seismic reflection projects.

A major issue reflected in the survey concerns the coordination of support for geophysics between NERC and the Science and Engineering Research Council

\section{UK science parks}

THE year 1984 looks set to be a bumper one for science parks in Britain. Although opinions differ on what they should do and even on what they are, everyone is convinced they are a good thing and should be encouraged. So far this year, the University of Birmingham has officially launched its grandly-styled "Institute of Research and Development", Barclay's Bank has opened a "Venture Centre" at the plain old science park at the University of Warwick, while the University of Stirling hopes this week to reach agreement with local authorities over its long-delayed proposed science park (not to be confused with the High Technology Area, over which the university relinquished control by selling it to Wang computers). Even the polytechnics are getting in on the act: the Polytechnic of the South Bank this week plans to open its "Technopark" on a derelict site in South London.

Connoisseurs of the species would probably object to the last-mentioned being described as a science park, since it is neither exclusively scientific nor park-like. There is a distinction to be drawn between science parks opened in the north of England, which have been seized upon by local authorities as a regional development tool (as well as by universities as a source of extra income), and the more spontaneous southern type. And investors are becoming more wary of the idea of science parks, some of which seem hard to distinguish from up-market of fice accommodation.

As these enterprises were seen chiefly as a means of attracting new industry to depressed areas it may, however, be unfair to judge them too harshly. The true science
(SERC), an issue that seems to occupy the minds of UK geophysicists of all persuasions. Indeed, the Royal Society working party looking into support for geophysics as a whole (including atmospheric and magnetospheric science as well as the Earth sciences) was stimulated to do so partly by the feeling in the communities that the atmospheric/space geophysicists are insufficiently strong in the competition for SERC funds compared with the astronomers, while some solid-Earth geophysicists feel unduly dominated by the geologists on the NERC committees.

That the research councils are aware of the problem is reflected in a recent meeting between Sir Hermann Bondi and Professor John Kingman, chairmen of NERC and SERC respectively. They concluded that the present distribution of responsibility between the councils is appropriate but that more attention needs to be given to the borders of responsibility. To this end, Dr John Mather (NERC) and Dr Barry Martin (SERC) have been given responsibility for ensuring adequate cooperation.

Philip Campbell

\title{
A growing phenomenon
}

park has to have a low building density and be in an attractive environment. One of the main lessons of the British experience so far is that the sort of people with ideas that will regenerate industry are rather fussy about where they want to live. Cultural amenities are as important as close proximity to a university, it seems: one recent study found that technology-minded companies are as likely to forge links with universities elsewhere in the country as with the one on their doorstep.

The investor, even if he has lost a little of his initial enthusiasm, is not yet totally disillusioned with science parks. Although seen by some universities as a panacea for all ills, few are likely to become mature investments within 15 years. The science park at Cambridge, the oldest in the business, is now said to be making a good commercial return on the investment of those who backed the project, although it has now relaxed its original rule against any manufacturing industry on the site. HeriotWatt University in Edinburgh has a research park, which it insists will never be sullied with manufacturing industry.

At Birmingham, the university has set up a management company to head its institute. It has been luckier than most in having "loads of money" to spend on the project, in the words of John Samuels, Birmingham's professor of business finance. Although it does not intend to follow others and tempt industries to move in by offering low rents, Professor Samuels says that several companies who want to collaborate with university academics are prepared to take the plunge.

Tim Beardsley 